\title{
Apelin abrogates the stimulatory effects of $17 \beta$-estradiol and insulin-like growth factor-1 on proliferation of epithelial and granulosa ovarian cancer cell lines via crosstalk between APLNR and ERa/IGF1R
}

\author{
Marta Hoffmann $^{1}$ (D) Justyna Gogola ${ }^{1}$ (D) . Anna Ptak ${ }^{1}$ (D)
}

Received: 27 April 2019 / Accepted: 10 September 2019 / Published online: 20 September 2019

(c) The Author(s) 2019

\begin{abstract}
Apelin and chemerin are adipocytokines that play important roles in many physiological and pathological processes throughout the body. Our previous study demonstrated that these two adipokines are expressed and secreted by epithelial and granulosa cancer cell lines. 17 $\beta$-estradiol (E2) and insulin-like growth factor-1 (IGF-1) are important regulators of ovarian functions, and their roles are well known. This study investigated whether apelin and chemerin regulate proliferation and apoptosis of epithelial (OVCAR-3) and granulosa (COV434) ovarian cancer cell lines by interacting with E2 and IGF-1. Apelin and chemerin did not affect caspase-3 activation in either cell line. However, apelin abrogated the stimulatory effects of E2 on proliferation of OVCAR-3 cells and of IGF-1 on proliferation of COV434 cells independently of ERK1/2 and PI3K via crosstalk of apelin receptor with estrogen receptor alpha and IGF-1 receptor, respectively.
\end{abstract}

Keywords Apelin $\cdot$ Chemerin $\cdot 17 \beta$-estradiol $\cdot$ IGF-1 $\cdot$ Ovarian cancer

$\begin{array}{ll}\text { Abbreviations } \\ \text { APLNR } & \text { Apelin receptor } \\ \text { E2 } & \text { 17 } \beta \text {-estradiol } \\ \text { ER } \alpha & \text { Estrogen receptor alpha } \\ \text { ER } \beta & \text { Estrogen receptor beta } \\ \text { GPR30 } & \text { G protein-coupled receptor } 30 \\ \text { G15 } & \text { GPR30 antagonist } \\ \text { IGF-1 } & \text { Insulin-like growth factor-1 } \\ \text { IGF1R } & \text { Insulin-like growth factor-1 receptor } \\ \text { LY294002 } & \text { Selective inhibitor of phosphatidylinositol } 3 \\ & \text { kinase selective inhibitor of phosphatidy } \\ \text { ML221 } & \text { Apelin receptor antagonist } \\ \text { MPP } & \text { Estrogen receptor alpha antagonist }\end{array}$

Marta Hoffmann

marta.hoffmann@doctoral.uj.edu.pl

Justyna Gogola

justyna.gogola@doctoral.uj.edu.pl

Anna Ptak

anna.ptak@uj.edu.pl

1 Department of Physiology and Toxicology of Reproduction, Institute of Zoology and Biomedical Research, Jagiellonian University in Krakow, Gronostajowa 9, 30-387 Kraków, Poland
$\mathrm{P} / \mathrm{A}$ ratio
Proliferation/apoptosis ratio
PD98059 Selective inhibitor of mitogen-activated pro- tein kinase kinases
PHTPP Estrogen receptor beta antagonist

\section{Introduction}

Adipose tissue is one of the largest endocrine organs in the body and has endocrinologic, metabolic, and immunoregulatory roles. The multifunctionality of adipose tissue is dependent on its ability to synthesize and release several bioactive compounds including hormones, cytokines, extracellular matrix proteins, and growth factors, which influence a variety of physiological and pathophysiological processes. Several reports indicate that ovarian cells express adipose tissue hormones, called adipokines, and their receptors [1-6]. Moreover, our previous studies demonstrated that ovarian cancer cells express adipokine receptors and also synthesize and secrete adipokines such as apelin [7] and chemerin [8]. These findings suggest that apelin and chemerin have paracrine and autocrine actions in ovarian cancer cells. 
Apelin is a $9 \mathrm{kDa}$ protein that functions as an endogenous ligand of the orphan $\mathrm{G}$ protein-coupled apelin receptor (APLNR) and is expressed in various tissues throughout the body $[9,10]$. The serum concentration of apelin is approximately $1.31 \pm 0.12 \mathrm{ng} / \mathrm{ml}$ [11]. Our laboratory recently reported that the basal apelin concentration in epithelial and granulosa cancer cells is approximately 0.4 and $0.6 \mathrm{ng} /$ $\mathrm{ml}$, respectively [7]. Apelin is a multifunctional regulatory peptide involved in a broad range of physiological and pathological functions, including energy metabolism, food intake, hormone release, immune responses, angiogenesis, and carcinogenesis [12-15]. Binding of apelin to its receptor activates the ERK and PI3K pathways in lymphatic endothelial cells, which increases their proliferation, migration, and survival [16, 17]. Recent studies demonstrated that apelin expression is increased in various cancers, including those of the colon [18], lung [13, 19], and oral cavity [20].

Chemerin, also known as tazarotene-induced gene 2 (TIG-2) and retinoic acid receptor responder 2 (RARRES2), is an $18 \mathrm{kDa}$ inactive pro-protein that is activated via removal of a C-terminal hexapeptide by extracellular serine proteases and binds to $\mathrm{G}$ protein-coupled chemokinelike receptor 1 (CMKLR1) [21]. The serum concentration of chemerin is positively correlated with body fat, visceral adipose tissue, and serum triglycerides [22, 23], and reportedly ranges from 7 to $270 \mathrm{ng} / \mathrm{ml}$ [24-27]. Our previous study indicated that the basal chemerin concentration in epithelial and granulosa cancer cells is approximately 11.1 and $3.6 \mathrm{ng} /$ $\mathrm{ml}$, respectively [8]. Chemerin derived from adipose tissue is involved in adipogenesis, differentiation, and chemotaxis in the innate immune system [28]. In primary human granulosa cells, chemerin decreases insulin-like growth factor-1 (IGF1)-induced thymidine incorporation as well as progesterone and estradiol production via decreased phosphorylation of the $\beta$ subunit of IGF- 1 receptor (IGF1R) and the MAPK/ ERK1/2 signaling pathways [29].

Ovarian cancer is the seventh most commonly diagnosed cancer in women worldwide and is the leading cause of death from gynecological malignancies [30]. Due to its non-specific symptoms, most cases of ovarian cancer present at a late stage. Unfortunately, the 5 year relative survival rate is only $29 \%$ [31]. Nearly all benign and malignant ovarian tumors originate from one of three cell types: epithelial, stromal, and germ cells. Epithelial ovarian cancer is the most common pathologic subtype and accounts for $90 \%$ of malignant ovarian tumors, while 5-6\% of such tumors are sex cord-stromal tumors (e.g., granulosa cell tumors and thecomas) and 2-3\% are germ cell tumors (e.g., teratomas and dysgerminomas) [32].

Estrogens play a key role in ovarian cancer progression. $17 \beta$-estradiol (E2), which is the most potent naturally occurring estrogen, is implicated in the etiology and pathogenesis of ovarian cancer [33]. Estrogens promote tumor progression by binding to nuclear estrogen receptor alpha (ER $\alpha)$, estrogen receptor beta $(E R \beta)$, or $G$ protein-coupled receptor 30 (GPR30), a novel membrane receptor that promotes specific binding of endogenous estrogens. Proper functioning of the female reproductive system is dependent on several important factors that constantly interact with each other. IGF-1 and IGF1R are key intraovarian regulators of oocyte development, including folliculogenesis, atresia, steroidogenesis, and oocyte maturation. IGF-1 stimulates ovarian cancer cell proliferation, invasion, and angiogenesis [34-36]. Additionally, overexpression of IGF-1 and IGF1R is associated with ovarian cancer progression and correlates with a poor prognosis. Crosstalk between IGF-1 signaling and estrogen signaling may be important for functional regulation in ovarian cancer cells. Additionally, crosstalk between the IGF-1 pathway and ER $\alpha$ is well studied in breast cancer cells [37]. E2, IGF-1, apelin, and chemerin activate the same signaling pathways; therefore, we hypothesized that crosstalk may occur between these hormones in ovarian cancer cells.

Thus, this study investigated whether apelin and chemerin at concentrations measured in human ovaries and serum interact with E2 and IGF-1 to regulate proliferation and apoptosis of epithelial (OVCAR-3) and granulosa (COV434) ovarian cancer cell lines. We also examined which signaling pathways are involved in these actions.

\section{Materials and methods}

\section{Cell culture and chemicals}

The OVCAR-3 human ovarian serous carcinoma cell line was obtained from the American Type Culture Collection (Manassas, VA, USA). The COV434 granulosa ovarian tumor cell line was obtained from the European Collection of Authenticated Cell Cultures (Sigma-Aldrich, St. Louis, MO, USA). OVCAR-3 cells were cultured in RPMI 1640 medium (Thermo Fisher Scientific Inc., Carlsbad, CA, USA) supplemented with $15 \%$ heat-inactivated fetal bovine serum (Biowest, Nuaillé, France). COV434 cells were cultured in DMEM (Sigma-Aldrich) supplemented with $2 \mathrm{mM}$ L-glutamine (Thermo Fisher Scientific) and $10 \%$ fetal bovine serum. All cultures were maintained at $37{ }^{\circ} \mathrm{C}$ in a humidified atmosphere containing $5 \% \mathrm{CO}_{2}$.

Apelin-13 (Cat. No. A6469) and E2 (Cat. No. E2785) were obtained from Sigma-Aldrich. Chemerin (16 kDa; Cat. No. 2324-CM-025) was purchased from R\&D Systems (Minneapolis, MN, USA). IGF-1 (Cat. No. PHG0071) was obtained from Gibco (Thermo Fisher Scientific). E2 was dissolved in absolute ethanol, while IGF-1 was dissolved in Cell Culture Water containing $0.1 \%$ bovine serum albumin (Thermo Fisher Scientific). 1,3-Bis(4-hydroxyphenyl)4-methyl-5-[4-(2-piperidinylethoxy)phenol]-1H-pyrazole 
dihydrochloride (MPP dihydrochloride), 4-[2-phenyl5,7-bis(trifluoromethyl)pyrazolo[1,5-a]pyrimidin-3-yl] phenol (PHTPP), 2-(2-amino-3-methoxyphenyl)-4H-1-benzopyran-4-one (PD98059), (3aS*,4R*,9bR*)-4-(6-bromo1,3-benzodioxol-5-yl)-3a,4,5,9b-3H-cyclopenta[c]quinoline (G15), and 5-[(4-nitrobenzoyl)oxy]-2-[(2-pyrimidinylthio) methyl]-4H-pyran-4-one (ML221) were purchased from Tocris Bioscience (Bristol, UK). LY294002 was obtained from Cell Signaling Technology (Danvers, MA, USA). MPP, PHTPP, PD98059, G15, ML221, and LY294002 were dissolved in DMSO. The final concentration of ethanol or DMSO in the cell culture medium was lower than $0.1 \%$ $(\mathrm{v} / \mathrm{v})$, which did not affect cell viability. Control cells were treated with the appropriate solvent alone at a final concentration lower than $0.1 \%$.

\section{Cell treatment}

OVCAR-3 and COV434 cells were seeded into 96-well plates at $70 \%$ confluency in standard medium and cultured for $24 \mathrm{~h}$. To investigate the effects of apelin $(0.4,0.6$, and $2 \mathrm{ng} / \mathrm{ml})$ and chemerin $(3,10$, and $50 \mathrm{ng} / \mathrm{ml})$ together with E2 $(1 \mathrm{nM})$ or IGF-1 $(100 \mathrm{ng} / \mathrm{ml})$ on cell proliferation, cells was treated with the test compounds for 48 or $72 \mathrm{~h}$. To investigate the involvement of signal transduction pathways in the effects of the test compounds on cell proliferation, cells were pretreated with the MAPK inhibitor PD098059 $(5 \mu \mathrm{M})$ or the PI3K inhibitor LY294002 $(0.1 \mu \mathrm{M})$ for $2 \mathrm{~h}$. The concentrations of inhibitors were chosen based on preliminary dose-dependent experiments. To investigate the involvement of specific receptors in the effects of the test compounds, cells were pretreated with selective antagonists of ER $\alpha$ (MPP; $10 \mathrm{nM}$ ), ER $\beta$ (PHTPP; $100 \mathrm{nM}$ ), GPR30 (G15; 1 $\mu \mathrm{M}$ ), and IGF1R (PPP; $100 \mathrm{nM}$ ) for $2 \mathrm{~h}$ and then exposed to the test compounds for 48 or $72 \mathrm{~h}$.

\section{Real-time PCR analysis}

Total RNA was isolated and cDNA was synthesized at baseline and after treatment with apelin and chemerin alone for $24 \mathrm{~h}$ using a TaqMan Gene Expression Cells-to-CT Kit (Applied Biosystems, Foster City, CA, USA) according to the manufacturer's instructions. The lysis solution contained DNase I to remove genomic DNA contamination. The resulting pre-amplified cDNA preparations were analyzed by real-time PCR using a StepOnePlus Real-Time PCR System (Applied Biosystems) and TaqMan Gene Expression Assays in combination with TaqMan Gene Expression Master Mix containing ROX Reference Dye (Applied Biosystems). The thermal cycling conditions were as follows: $50^{\circ} \mathrm{C}$ for $2 \mathrm{~min}, 95^{\circ} \mathrm{C}$ for $10 \mathrm{~min}$, and then 40 cycles of $95^{\circ} \mathrm{C}$ for $15 \mathrm{~s}$ and $60^{\circ} \mathrm{C}$ for $60 \mathrm{~s}$. The following TaqMan gene expression assays were used: $\mathrm{ER} \alpha$ (ESR1; Hs00174860_m1), ER $\beta$
(ESR2; Hs01100353_ml), GPR30 (GPER; Hs01922715_sl), and IGF1R (IGF1R; Hs00609566_ml). Expression levels were normalized against that of GADPH (Assay No. 4310884E). Relative expression was quantified using the $2^{-\Delta \Delta \mathrm{Ct}}$ method [38].

\section{Cell proliferation assay}

Cell proliferation was assessed using the CellTiter-Glo Luminescent Cell Viability Assay (Promega, Charbonnieresles-Bains, France), which determines the number of viable cells based on quantitation of ATP, an indicator of metabolically active cells. Luminescence was measured using a SpectraMax L luminometer (Molecular Devices, San Jose, CA, USA) according to the manufacturer's instructions.

\section{Caspase- 3 activity assay}

The culture medium was replaced by serum-free medium $24 \mathrm{~h}$ prior to the experiment. Cells were treated with vehicle, apelin $(0.4,0.6$, and $2 \mathrm{ng} / \mathrm{ml})$, or chemerin $(3,10$, and $50 \mathrm{ng} / \mathrm{ml}$ ) for $24 \mathrm{~h}$. The medium was then removed, and the plates were stored at $-70{ }^{\circ} \mathrm{C}$. Cells were lysed in caspase assay buffer (50 mM HEPES, pH 7.4, $100 \mathrm{mM} \mathrm{NaCl}, 0.1 \%$ CHAPS, 1 mM EDTA, $10 \%$ glycerol, and $10 \mathrm{mM}$ DTT). The protein concentrations of the lysates were determined using the reactive compound fluorescamine (MP Biomedicals, Illkirch Cedex, France). An equal amount of the cytosolic extract (100 $\mu \mathrm{g}$ of protein) from each sample was analyzed. The assay was performed by adding $100 \mu \mathrm{M}$ Ac-DEVDAMC (Sigma-Aldrich) and incubating the plates at $37^{\circ} \mathrm{C}$. The amount of fluorescent product was monitored continuously for 120 min using a spectrofluorometer (FLx800; BioTek Instruments, Winooski, VT, USA) at an excitation wavelength of $355 \mathrm{~nm}$ and an emission wavelength of $460 \mathrm{~nm}$. Data were analyzed using KC JUNIOR software and normalized against the level of fluorescence in vehicle-treated cells.

\section{Western blot analysis}

After treating cells with test compounds for 24 or $48 \mathrm{~h}$, cells were lysed in lysis buffer. Proteins were separated in 4-20\% Mini-Protean TGX System Precast Protein Gels (Bio-Rad, Hercules, CA, USA) and transferred to TransBlot Turbo Mini PVDF Transfer Packs (Bio-Rad) using a Trans- Blot Turbo Transfer System apparatus (Bio-Rad). The blots were blocked for $1 \mathrm{~h}$ in $0.02 \mathrm{M}$ Tris-buffered saline containing $5 \%$ bovine serum albumin and $0.1 \%$ Tween 20 and then incubated overnight at $4{ }^{\circ} \mathrm{C}$ with antibodies specific for caspase-3 and cleaved caspase-3 (\#9662, Cell Signaling Technology), PARP (\#9542, Cell Signaling Technology), ER $\alpha$ (sc-8002, Santa Cruz 
Biotechnology), ER $\beta$ (sc-8974, Santa Cruz Biotechnology), and GPR30 (ab3974, Abcam). The membranes were then washed three times in TBST (Tris-buffered saline, $0.1 \%$ Tween 20 ) and incubated for $1 \mathrm{~h}$ at room temperature with horseradish peroxidase (HRP)-conjugated antirabbit (\#7074) secondary antibodies (Cell Signaling Technology). $\beta$-Actin (Cat. No. A5316, Sigma-Aldrich) was used as a loading control. Immunopositive bands were visualized using WesternBright Quantum HRP substrate (Cat. No. K- 12043 D20, Advansta Inc., Menlo Park, CA, USA). Quantification of protein bands was performed by densitometry using VisionWorks LS Acquisition and Analysis software (UVP, LLC, Upland, CA, USA).

\section{Statistical analysis}

Data are presented as the mean \pm SD of three independent experiments performed in triplicate. Statistical analysis was performed using a one-way ANOVA followed by Tukey's test (GraphPad Prism Software, La Jolla, CA, USA). The level of significance was set at $P<0.05$. Proliferation and apoptosis were compared between two groups using the non-parametric Mann-Whitney $U$ test. $P<0.05$ was considered statistically significant.

\section{Results}

Our recent studies showed that OVCAR-3 cells secrete apelin and chemerin at concentrations of 0.4 and $10 \mathrm{ng} /$ $\mathrm{ml}$, respectively, while COV434 cells secrete apelin and chemerin at concentrations of 0.6 and $3 \mathrm{ng} / \mathrm{ml}$, respectively [7,8]. Therefore, apelin and chemerin were used at these concentrations in the current study. As mentioned in section "Introduction", adipokines are expressed in various tissues in the human body and function in paracrine and autocrine manners. Therefore, we considered the serum concentrations. Consequently, we also used apelin and chemerin at concentrations of 2 and $50 \mathrm{ng} / \mathrm{ml}$, respectively, based on their average serum concentrations.

\section{Effects of apelin and chemerin on the proliferation/ apoptosis $(\mathrm{P} / \mathrm{A})$ ratio}

The pro-carcinogenic effects of adipokines are not only due to increased activity of signaling pathways involved in proliferation, but probably also to downregulation of apoptosis. Therefore, we assessed the effects of apelin and chemerin on the P/A ratio of OVCAR-3 and COV434 cells. Apoptosis was evaluated by measuring caspase- 3 activity after treatment with apelin or chemerin for $24 \mathrm{~h}$. Apelin $(0.4$ or 0.6

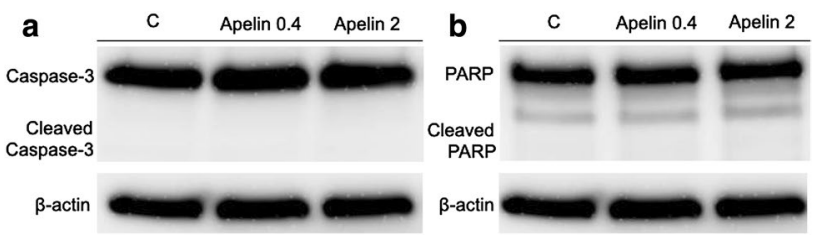

Fig. 1 Effect of apelin ( 0.4 and $2 \mathrm{ng} / \mathrm{ml})$ on $\mathbf{a}$ caspase- 3 and $\mathbf{b}$ cleaved PARP protein expression in OVCAR-3 cells after $48 \mathrm{~h}$ of treatment. $C$ control

and $2 \mathrm{ng} / \mathrm{ml}$ ) and chemerin ( 3 or 10 and $50 \mathrm{ng} / \mathrm{ml}$ ) did not affect caspase- 3 activity in either cell line. Proliferation was evaluated by determining the number of viable cells based on quantitation of ATP, an indicator of metabolically active cells, and then the P/A ratio was calculated. Apelin significantly increased the $\mathrm{P} / \mathrm{A}$ ratio of OVCAR-3 cells $(\mathrm{P} / \mathrm{A}=1.16$, $P=0.0006$ for $0.4 \mathrm{ng} / \mathrm{ml}$; and $\mathrm{P} / \mathrm{A}=1.21, P<0.0001$ for $2 \mathrm{ng} / \mathrm{ml}$ ), but did not significantly affect that of COV434 cells. Caspase- 3 as a crucial executioner of apoptosis, is also responsible for the proteolytic cleavage of many key proteins. Cleavage and therefore activation of caspase-3 leads to cleavage of nuclear enzyme Poly (ADP-ribose) polymerase (PARP) that is known to be a terminal step of apoptosis. Thus, we evaluated the effect of apelin on caspase- 3 , cleaved caspase- 3 as well as cleaved PARP protein expression in OVCAR-3 cells. Apelin at all tested concentrations had no effect on OVCAR-3 caspase-3 and cleaved PARP protein expression (Fig. 1a, b). Chemerin did not significantly affect the P/A ratio of either cell line (Table $1 ; P>0.05$ ). These results indicate that apelin increases proliferation of OVCAR-3 cells, but does not affect apoptosis.

\section{Effects of apelin and chemerin in combination with $\mathrm{E} 2$ on cell proliferation}

Apelin and E2 were previously reported to affect proliferation of epithelial ovarian cancer cells. This prompted us to investigate the effects of co-treatment with apelin and $\mathrm{E} 2$ on cell proliferation. Consistent with the previous results, treatment with apelin at concentrations measured in epithelial ovarian cancer cells $(0.4 \mathrm{ng} / \mathrm{ml})$ and serum $(2 \mathrm{ng} / \mathrm{ml})$ increased proliferation of OVCAR-3 cells $(114 \pm 4 \%$ and $115 \pm 4 \%$ relative to that of control cells, respectively) (Fig. 2a; $P<0.001)$. Similarly, E2 $(1 \mathrm{nM})$ increased proliferation of OVCAR-3 cells $(112 \pm 4 \%)$ (Fig. $2 \mathrm{a} ; P<0.05$ ). However, apelin abrogated the E2-induced increase in OVCAR-3 cell proliferation; cotreatment with apelin and E2 decreased proliferation to the control level $(99 \pm 3 \%$ and $99 \pm 1 \%$ upon co-treatment with $\mathrm{E} 2$ and 0.4 or $2 \mathrm{ng} / \mathrm{ml}$ apelin, respectively) (Fig. 2a). Furthermore, apelin and E2 did not affect proliferation of COV434 cells (Fig. 2b). 
Table 1 Effects of (a) apelin ( 0.4 or 0.6 and $2 \mathrm{ng} / \mathrm{ml}$ ) and (b) chemerin (3 or 10 and $50 \mathrm{ng} / \mathrm{ml}$ ) on proliferation and apoptosis of OVCAR-3 and COV434 cells

\begin{tabular}{|c|c|c|c|c|}
\hline \multirow[t]{3}{*}{ (a) } & \multicolumn{2}{|l|}{ OVCAR-3 } & \multicolumn{2}{|l|}{ COV434 } \\
\hline & \multicolumn{4}{|l|}{ Apelin } \\
\hline & $0.4 \mathrm{ng} / \mathrm{ml}$ & $2 \mathrm{ng} / \mathrm{ml}$ & $0.6 \mathrm{ng} / \mathrm{ml}$ & $2 \mathrm{ng} / \mathrm{ml}$ \\
\hline Proliferation (\%) & $114.1 \pm 4.3$ & $115.5 \pm 4.3$ & $97.8 \pm 8.9$ & $103.1 \pm 9.4$ \\
\hline Apoptosis (\%) & $97.1 \pm 8.2$ & $95.1 \pm 11.5$ & $102.3 \pm 10.2$ & $97.1 \pm 9.7$ \\
\hline Proliferation/apoptosis ratio & $1.16^{* * *}$ & $1.21 * * *$ & 0.96 & 1.06 \\
\hline \multirow[t]{3}{*}{ (b) } & \multicolumn{2}{|l|}{ OVCAR-3 } & \multicolumn{2}{|l|}{ COV434 } \\
\hline & \multicolumn{4}{|l|}{ Chemerin } \\
\hline & $10 \mathrm{ng} / \mathrm{ml}$ & $50 \mathrm{ng} / \mathrm{ml}$ & $3 \mathrm{ng} / \mathrm{ml}$ & $50 \mathrm{ng} / \mathrm{ml}$ \\
\hline Proliferation $(\%)$ & $109.2 \pm 8.5$ & $109.2 \pm 10.1$ & $102.2 \pm 6.5$ & $106.5 \pm 6.4$ \\
\hline Apoptosis (\%) & $93.7 \pm 16.1$ & $97.0 \pm 37.6$ & $102.7 \pm 17.4$ & $107.5 \pm 19.4$ \\
\hline Proliferation/apoptosis ratio & 1.17 & 1.13 & 0.96 & 0.99 \\
\hline
\end{tabular}

Apoptosis and proliferation were assessed by measuring caspase-3 activity and quantifying ATP, respectively, as described in section "Materials and methods". Results are presented as the mean $\pm \mathrm{SD}$

$* * * P<0.05$ (compared with control untreated cells)
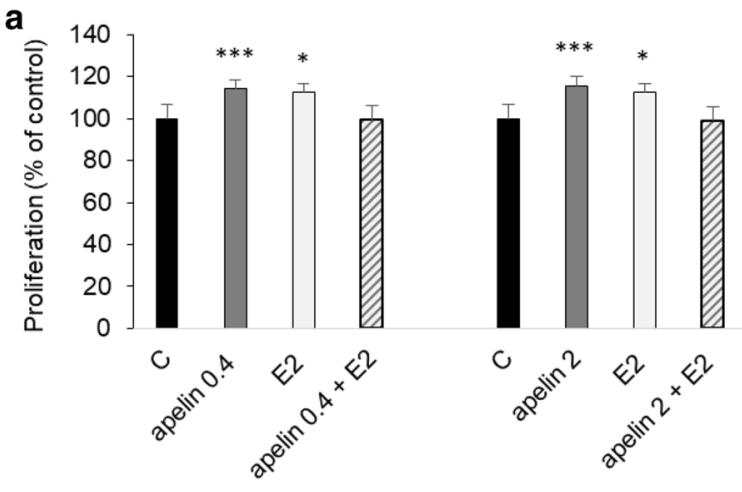

C

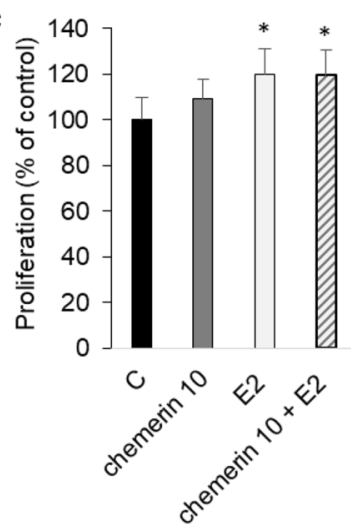

Fig. 2 Effect of apelin $(0.4$ or 0.6 and $2 \mathrm{ng} / \mathrm{ml})$ in combination with E2 $(1 \mathrm{nM})$ on proliferation of a OVCAR-3 and b COV434 cells. Effect of chemerin (3 or 10 and $50 \mathrm{ng} / \mathrm{ml}$ ) in combination with E2

Next, we examined the effect of co-treatment with chemerin and E2 on proliferation of OVCAR-3 and b

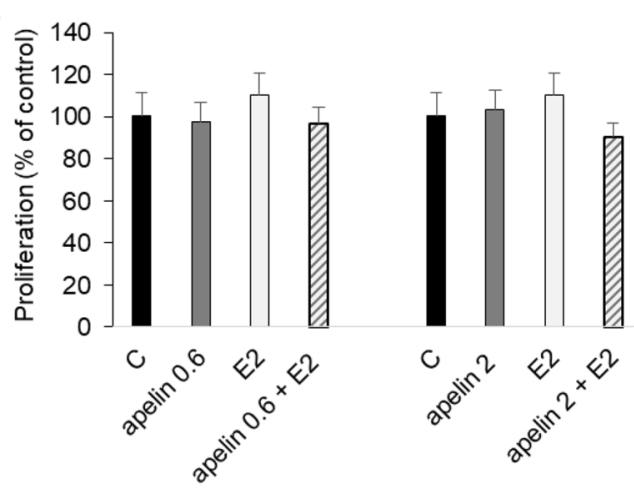

d

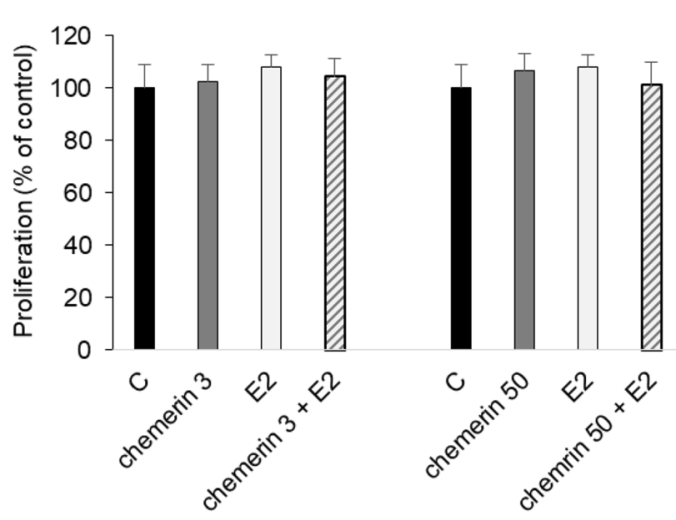

$(1 \mathrm{nM})$ on proliferation of $\mathbf{c}$ OVCAR-3 and d COV434 cells. $C$ control. $* P<0.05, * * * P<0.001$ (compared with control untreated cells)

COV434 cells. According to our previous study, chemerin did not affect proliferation of either cell line. Consistently, 

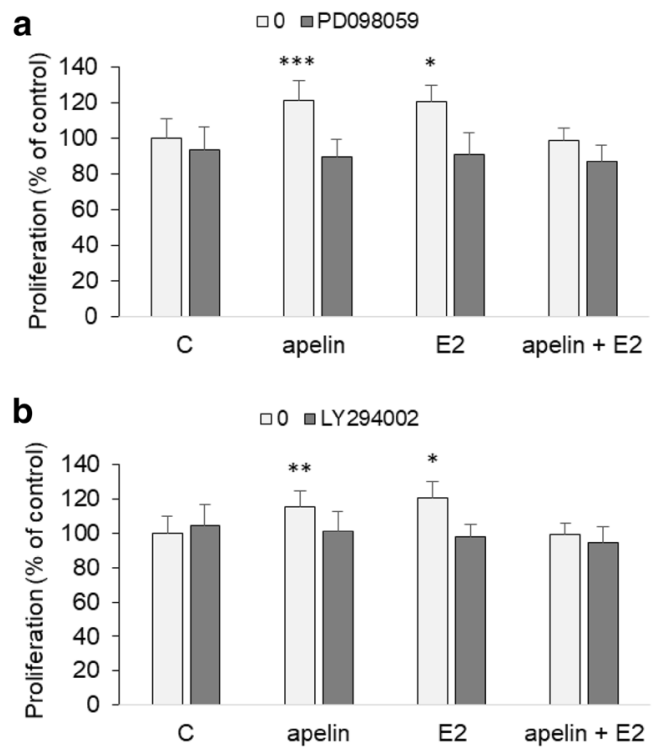

Fig. 3 Influence of a ERK1/2 and b PI3K inhibition on the effects of apelin $(2 \mathrm{ng} / \mathrm{ml})$ and E2 on OVCAR-3 cell proliferation. Cells were pretreated with the ERK1/2 inhibitor PD098059 $(5 \mu \mathrm{M})$ or the PI3K inhibitor LY294002 $(0.1 \mu \mathrm{M})$ for $2 \mathrm{~h}$ and then exposed to the indicated test compounds for $48 \mathrm{~h}$ (in the presence of inhibitors). $C$ control (not exposed to a test compound). ${ }^{*} P<0.05$, $* * * P<0.001$ (compared with control untreated cells)

chemerin (10 and $50 \mathrm{ng} / \mathrm{ml}$ ) did not affect proliferation of OVCAR-3 cells. Moreover, chemerin did not influence the stimulatory effect of E2 $(1 \mathrm{nM})$ on proliferation of OVCAR-3 cells (Fig. 2c). Treatment with chemerin alone (3 and $50 \mathrm{ng} / \mathrm{ml})$ or in combination with E2 $(1 \mathrm{nM})$ did not affect proliferation of COV434 cells (Fig. 2d).

Based on these results, subsequent experiments were conducted to investigate the antagonistic effect of apelin on E2-induced proliferation of OVCAR-3 cells.

\section{Mechanism by which apelin abrogates E2-induced proliferation of OVCAR-3 cells}

\section{Role of the ERK1/2 and PI3K pathways in the effects of apelin on E2-induced proliferation of OVCAR-3 cells}

We investigated whether the ERK1/2 and PI3K pathways are involved in the antagonistic effect of apelin on E2-induced proliferation of OVCAR-3 cells. Pretreatment with the ERK1/2 inhibitor PD098059 $(5 \mu \mathrm{M})$ for $2 \mathrm{~h}$ prior to exposure to the test compounds for $48 \mathrm{~h}$ abrogated the stimulatory effects of apelin $(2 \mathrm{ng} / \mathrm{ml})$ and E2 $(1 \mathrm{nM})$ alone on cell proliferation. Co-treatment with apelin and E2 following pretreatment with PD098059 did not affect cell proliferation (Fig. 3a). These data indicate that the
ERK1/2 pathway is not involved in the antagonistic effect of apelin on E2-induced proliferation of OVCAR-3 cells.

We next investigated whether blockade of the PI3K pathway abrogates the antagonistic effect of apelin on E2-induced proliferation of OVCAR-3 cells. Pretreatment with the PI3K inhibitor LY294002 $(0.1 \mu \mathrm{M})$ abrogated the stimulatory effects of E2 and apelin alone on cell proliferation. Co-treatment with apelin and E2 following pretreatment with LY294002 did not affect cell proliferation (Fig. 3b). These data suggest that the PI3K pathway is not involved in the antagonistic effect of apelin on E2-induced proliferation of OVCAR-3 cells.

\section{Role of APLNR, ERa, ER $\beta$, and GPR30 in the effects of apelin on E2-induced proliferation of OVCAR-3 cells}

To elucidate how apelin abrogates E2-induced proliferation of OVCAR-3 cells, we assessed its effect on classical ( $E R \alpha$ and $E R \beta$ ) and non-classical (GPR30) estrogen receptors. Apelin $(0.4$ and $2 \mathrm{ng} / \mathrm{ml})$ did not affect expression of $E R \alpha, E R \beta$, and GPR30 in OVCAR-3 cells (Fig. 4a-c). After treating OVCAR-3 cells with apelin the ER $\alpha$, ER $\beta$, and GPR30 protein levels were examined by Western blot analysis, and the results mirrored those from real-time PCR analyses (Fig. 4d-f). This result suggests that apelin does not abrogate E2-induced proliferation of OVCAR-3 cells by changing estrogen receptor expression.

To investigate the mechanism by which apelin $(2 \mathrm{ng} / \mathrm{ml})$ abrogates the stimulatory effect of E2 $(1 \mathrm{nM})$ on proliferation of OVCAR-3 cells, we pretreated cells with inhibitors of APLNR, ER $\alpha, E R \beta$, and GPR30 (ML221: $10 \mu \mathrm{M}$, MPP: $10 \mathrm{nM}$, PHTPP: $10 \mathrm{nM}$, and G15: $1 \mu \mathrm{M}$, respectively) for $2 \mathrm{~h}$ and then exposed them to apelin and E2 for $48 \mathrm{~h}$. As expected, ML221 abolished the stimulatory effect of apelin on cell proliferation $(121 \pm 10 \%$ vs. $102 \pm 11 \%)$ (Fig. $4 \mathrm{~g}$ ). Cell proliferation upon co-treatment with apelin and E2 was similar regardless of whether cells were pretreated with or without ML221 (104 $\pm 10 \%$ vs. $103 \pm 8 \%)$ (Fig. 4g). Similarly, MPP abolished the stimulatory effect of apelin on cell proliferation $(102 \pm 7 \%)$. Cell proliferation upon cotreatment with apelin and E2 following pretreatment with MPP was similar to that of control cells $(96 \pm 6 \%)$ (Fig. 4h). However, apelin still increased cell proliferation following pretreatment with PHTPP or G15 $(119 \pm 7 \%$ and $117 \pm 6 \%$, respectively), and this effect was blocked in the presence of E2 (Fig. 4i, j). These results demonstrate that ER $\beta$ and GPR30 are not involved in the effects of apelin and E2 on cell proliferation and indicate that crosstalk occurs between APLNR and ER $\alpha$. 

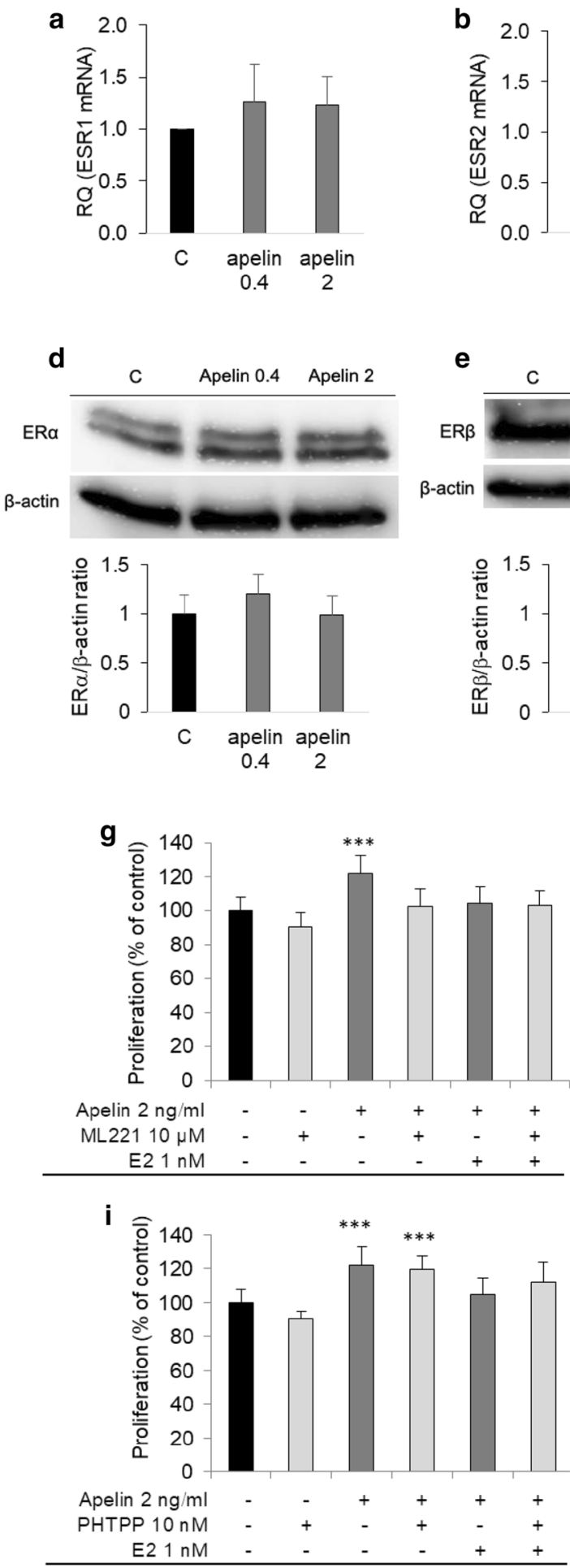

Fig. 4 Effects of treatment with apelin $(0.4$ and $2 \mathrm{ng} / \mathrm{ml})$ on mRNA $(\mathbf{a}-\mathbf{c})$ and protein $(\mathbf{d}-\mathbf{f})$ expression of $\mathrm{ER} \alpha, \mathrm{ER} \beta$, and GPR30 in OVCAR-3 cells. RQ, relative quantity. The expression level in control cells was arbitrarily set to 1 . Role of $\mathbf{g}$ APLNR, $\mathbf{h}$ ER $\alpha, \mathbf{i} E R \beta$, and $\mathbf{j}$ GPR30 in the effects of apelin $(2 \mathrm{ng} / \mathrm{ml})$ and E2 $(1 \mathrm{nM})$ on OVCAR-3
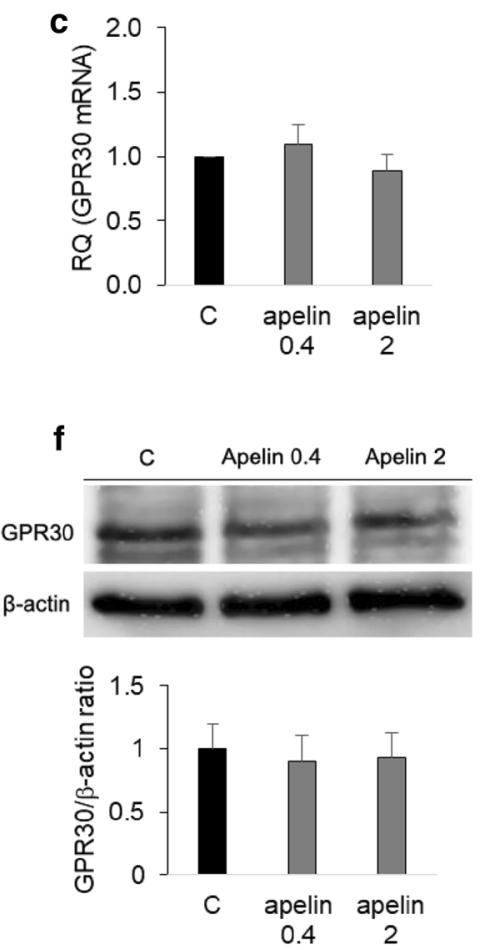

h

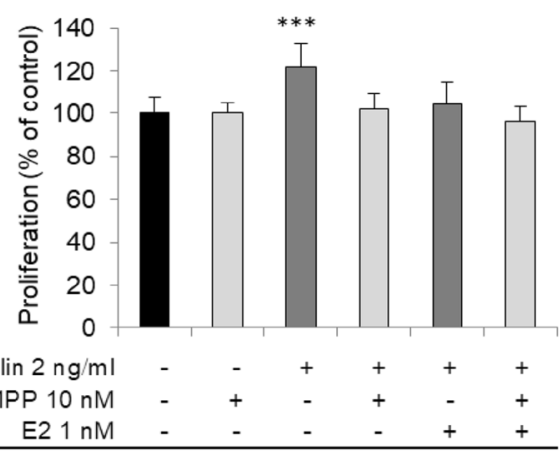

j

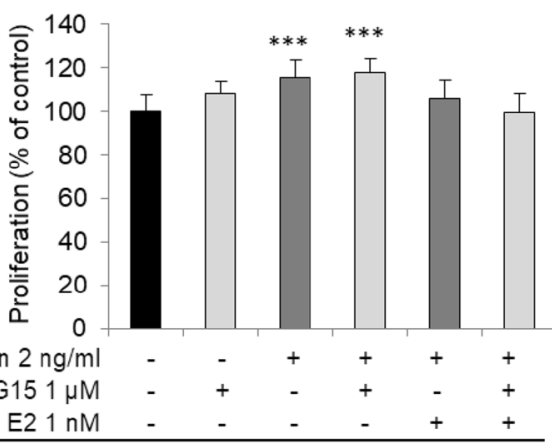

cell proliferation. Cells were pretreated with APLNR, ER $\alpha, \mathrm{ER} \beta$, and GPR30 inhibitors (ML221: $10 \mu \mathrm{M}$, MPP: $10 \mathrm{nM}$, PHTPP: $10 \mathrm{nM}$, and G15: $1 \mu \mathrm{M}$, respectively) for $2 \mathrm{~h}$ and then exposed to apelin and E2. $* * * P<0.001$ (compared with control untreated cells) 

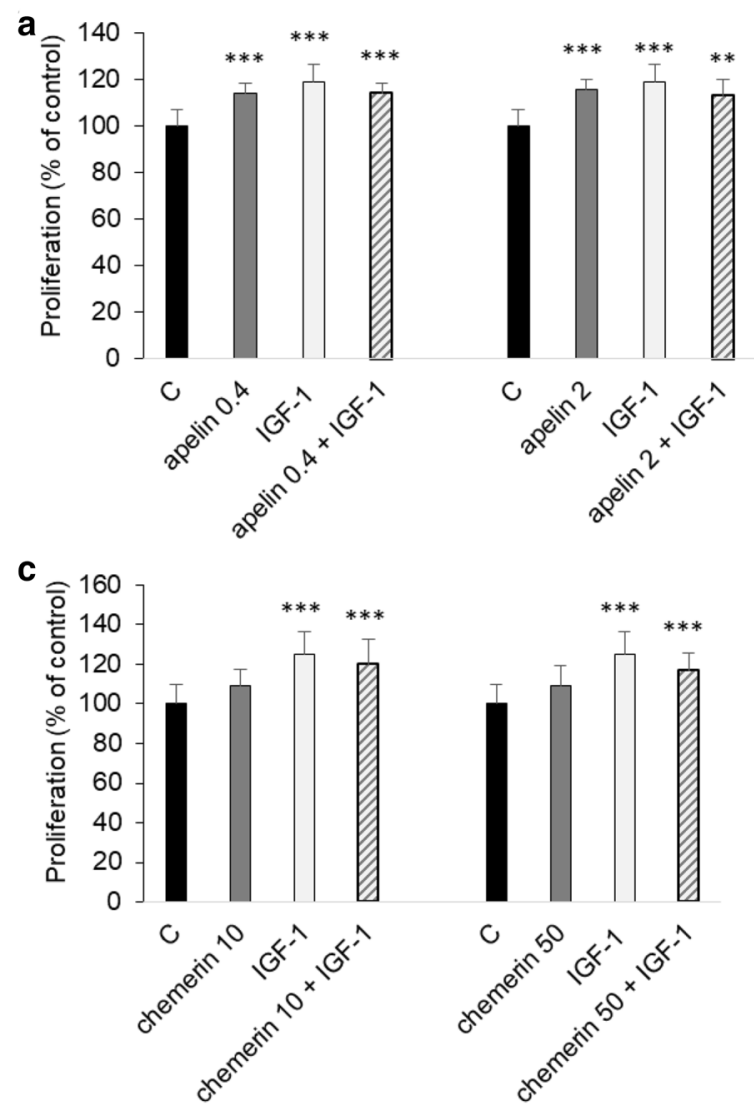

Fig. 5 Effect of apelin $(0.4$ or 0.6 and $2 \mathrm{ng} / \mathrm{ml})$ in combination with IGF-1 $(100 \mathrm{ng} / \mathrm{ml})$ on proliferation of a OVCAR-3 and b COV434 cells. Effect of chemerin ( 3 or 10 and $50 \mathrm{ng} / \mathrm{ml}$ ) in combination with

\section{Effects of apelin and chemerin in combination with IGF-1 on cell proliferation}

IGF-1 stimulates proliferation of epithelial and granulosa ovarian cancer cell lines. Therefore, we assessed the effects of co-treatment with apelin or chemerin and IGF-1 on cell proliferation. Treatment with IGF-1 $(100 \mathrm{ng} / \mathrm{ml})$ alone for $48 \mathrm{~h}$ significantly increased proliferation of OVCAR-3 and COV434 cells $(118 \pm 7 \%$ and $123 \pm 12 \%$, respectively) (Fig. $5 ; P<0.001)$. Apelin $(0.4$ and $2 \mathrm{ng} / \mathrm{ml})$ did not affect IGF-1-induced proliferation of OVCAR-3 cells. However, proliferation of COV434 cells was decreased to the control level upon co-treatment with apelin $(0.6$ and $2 \mathrm{ng} / \mathrm{ml})$ and IGF-1 (108 $\pm 10 \%$ and $111 \pm 10 \%$, respectively) (Fig. 5b). This result indicates that apelin antagonizes the stimulatory effect of IGF-1 on proliferation of COV434 cells.

Parallel experiments were conducted using chemerin and IGF-1. Chemerin did not affect cell proliferation and did not abrogate the stimulatory effects of IGF-1 on proliferation of either cell line (Fig. 5c, d). b
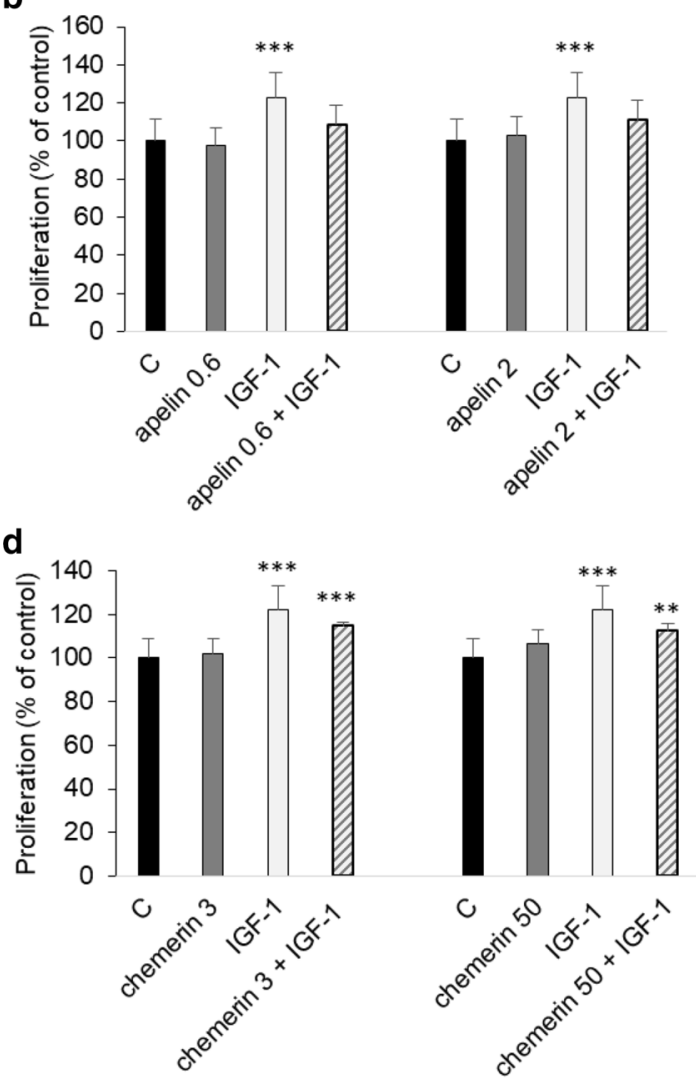

IGF-1 $(100 \mathrm{ng} / \mathrm{ml})$ on proliferation of $\mathbf{c}$ OVCAR-3 and d COV434 cells. $C$ control. $* * P<0.01, * * * P<0.001$ (compared with control untreated cells)

\section{Mechanism by which apelin abrogates IGF-1-induced proliferation of COV434 cells}

\section{Role of the ERK1/2 and PI3K pathways in the effects of apelin on IGF-1-induced proliferation of COV434 cells}

To investigate which signaling pathways are involved in the effects of apelin on IGF-1-induced proliferation of COV434 cells, cells was pretreated with the ERK1/2 inhibitor PD098059 $(5 \mu \mathrm{M})$ or the PI3K inhibitor LY294002 $(0.1 \mu \mathrm{M})$ for $2 \mathrm{~h}$ and then exposed to the test compounds for $48 \mathrm{~h}$. Blockade of the ERK1/2 and PI3K signaling pathways abrogated the stimulatory effect of IGF-1 $(100 \mathrm{ng} / \mathrm{ml})$ alone on cell proliferation, but did not influence the antagonistic effect of apelin ( $2 \mathrm{ng} / \mathrm{ml}$ ) on IGF-1-induced cell proliferation. These data indicate that the ERK1/2 and PI3K pathways are not involved in the antagonistic effect of apelin on IGF-1-induced proliferation of COV434 cells (Fig. 6). 

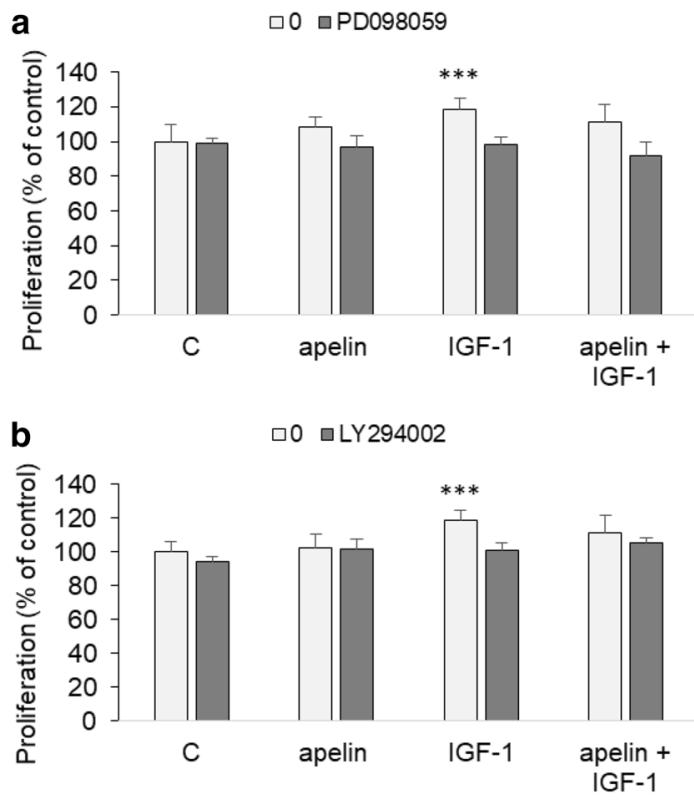

Fig. 6 Influence of a ERK1/2 and b PI3K inhibition on the effects of apelin $(2 \mathrm{ng} / \mathrm{ml})$ and IGF-1 on proliferation of COV434 cells. Cells were pretreated with the ERK1/2 inhibitor PD098059 $(5 \mu \mathrm{M})$ or the PI3K inhibitor LY294002 $(0.1 \mu \mathrm{M})$ for $2 \mathrm{~h}$ and then exposed to the indicated test compounds for $48 \mathrm{~h}$ (in the presence of the inhibitors). $C$ control (not exposed to a test compound). $* * * P<0.001$ (compared with control untreated cells)

a

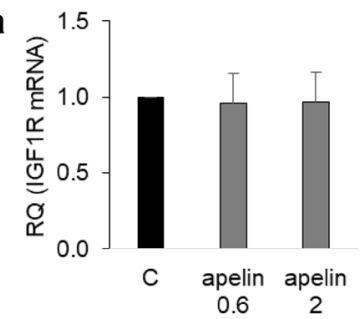$$
\text { b }
$$

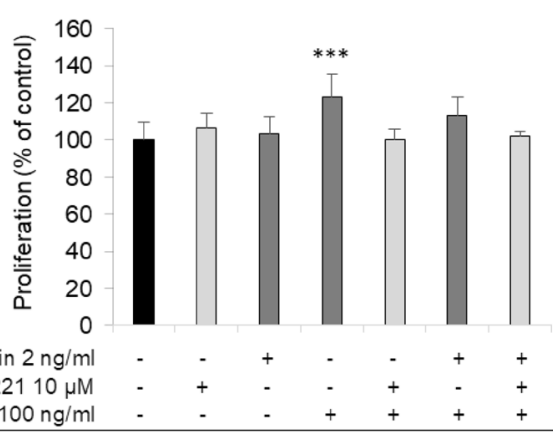

Fig. 7 a Effects of treatment with apelin $(0.6$ and $2 \mathrm{ng} / \mathrm{ml})$ for $24 \mathrm{~h}$ on mRNA expression of IGF1R in COV434 cells. $R Q$ relative quantity. The expression level in control cells was arbitrarily set to 1 . b The role of APLNR signaling in the effects of apelin $(2 \mathrm{ng} / \mathrm{ml})$ and IGF-1 $(100 \mathrm{ng} / \mathrm{ml})$. Cells were pretreated with the APLNR inhibitor ML221 $(10 \mu \mathrm{M})$ for $2 \mathrm{~h}$ and then exposed to apelin and IGF-1. ${ }^{* * *} P<0.001$ (compared with control untreated cells)
Role of the APLNR signaling pathway in the effects of apelin on IGF-1-induced proliferation of COV434 cells

To elucidate how apelin inhibits IGF-1-induced proliferation of COV434 cells, we assessed its effect on IGF1R expression. Apelin $(0.6$ and $2 \mathrm{ng} / \mathrm{ml})$ did not affect mRNA expression of IGF1R in COV434 cells (Fig. 7a). This result suggests that apelin does not abrogate IGF-1-induced proliferation of COV434 cells by altering IGF1R expression. The role of the APLNR pathway was further evaluated. Pretreatment with the APLNR inhibitor ML221 $(10 \mu \mathrm{M})$ abrogated the stimulatory effect of IGF-1 $(100 \mathrm{ng} / \mathrm{ml})$ on proliferation of COV434 cells (Fig. 7b). We conclude that apelin abrogates the stimulatory effect of IGF-1 on proliferation of COV434 cells via crosstalk between APLNR and IGF1R.

\section{Discussion}

Adipokines are present in the female reproductive system. In fact, adipokines and their receptors are expressed in human reproductive tissue and may thus act in an autocrine manner [39]. Our previous studies showed that apelin and chemerin are expressed in human ovarian cancer cell lines and that their expression ratio differs according to where the cells are derived from (epithelial vs. granulosa) [7, 8]. Thus, the present study investigated if apelin and chemerin influence apoptosis and proliferation of ovarian cancer cells by interacting with two major regulators of ovarian functions (E2 and IGF-1).

We investigated whether treatment with apelin and chemerin at concentrations measured in ovarian cancer cells and serum influences apoptosis of OVCAR-3 and COV434 cells. Apelin and chemerin did not significantly affect caspase- 3 activity, indicating that they do not activate apoptotic cell death, in which caspase- 3 is the executioner enzyme. Apelin only affected proliferation of epithelial ovarian cancer cells, consistent with our previous study [7]. Calculation of the P/A ratio revealed that apelin increased proliferation of OVCAR-3 cells, but did not inhibit apoptosis. However, inhibition of apoptosis is a hallmark of cancer and apoptosis is decreased in cancer cells. By contrast, previous studies suggest that apelin regulates apoptosis of various non-cancer cell types via different mechanisms. Apelin protects against apoptosis in cardiac tissues by regulating FoxO1 in mice [40] and by upregulating Bcl-2 and downregulating Bax together with cleaved caspase-3 in rats [41]. In addition, apelin alleviates oxidative stress and mitochondria-mediated apoptosis in mice [42]. Apelin induces expression of the antiapoptotic protein B cell lymphoma 2 and decreases production of the proapoptotic protein Bax in osteoblasts [43]. Moreover, apelin elicits a protective effect in the brain $[44,45]$ by inhibiting activation of the JNK and P38MAPK 
signaling pathway in damaged neurons [46]. Apelin also inhibits apoptosis of endothelial cells [47], retinal Muller cells [48], and smooth muscle cells [49]. However, Roche et al. [50] reported that apelin does not affect apoptosis of bovine granulosa cells. There is a lack of data concerning the influence of chemerin on apoptosis. Rodríguez-Penas et al. [51] reported that chemerin induces apoptosis, reduces AKT phosphorylation, and increases caspase- 9 cleavage in murine cardiomyocytes, suggesting that chemerin plays a role in the physiopathology of cardiac diseases.

Estrogen levels in ovarian tissue are at least 100 -fold higher than circulating levels, indicating that estrogens are implicated in progression of ovarian cancer [52]. Therefore, we next focused on the interaction of apelin and chemerin with E2. Treatment with apelin at concentrations measured in ovarian cancer cells and serum abrogated the stimulatory effect of E2 on proliferation of OVCAR-3 cells. Similarly, our previous study demonstrated that treatment with leptin or E2 alone stimulates migration of OVCAR-3 cells, while co-treatment does not [53]. Furthermore, adiponectin abrogates the stimulatory effect of E2 on proliferation of OVCAR-3 cells [54]. Upon co-treatment of COV434 cells with apelin and E2, the level of proliferation was similar to that of control cells. E2 affects proliferation of non-cancer granulosa cells [55], but not of granulosa tumor cells [56]. We next investigated which signaling pathways are involved in the antagonistic effect of apelin on E2-induced proliferation of OVCAR-3 cells. PD098059 and LY294002 were used to block the ERK1/2 and PI3K pathways, respectively. Cell proliferation induced by apelin or $\mathrm{E} 2$ alone was blocked by pretreatment with these inhibitors. This result is consistent with previous reports that ERK $1 / 2$ and PI3K function in E2-stimulated cancer progression. Additionally, we previously reported that E2 stimulates migration of OVCAR-3 cells via the ERK1/2 and PI3K pathways [57]. Apelin activates PI3K/Akt in human granulosa cells [58]. Activation of the ERK1/2 signaling pathway by apelin induces proliferation and invasion of MCF-7 cells [59]. Binding of apelin to its receptor activates the ERK and PI3K pathways in lymphatic endothelial cells, which increases their proliferation, migration, and survival $[16,17]$. However, the ERK1/2 and PI3K inhibitors did not affect the antagonistic effect of apelin on E2-induced proliferation of OVCAR-3 cells. These data indicate that apelin and E2 activate the same signaling pathways, but the ERK $1 / 2$ and PI3K pathways do not mediate the antagonistic effect of apelin on E2-induced proliferation of OVCAR-3 cells.

We also examined if apelin affects mRNA expression of classical (ER $\alpha$ and $E R \beta)$ and non-classical (GPR30) estrogen receptors. Apelin $(0.4$ and $2 \mathrm{ng} / \mathrm{ml})$ did not affect expression of these receptors in OVCAR-3 cells. Our previous study demonstrated that E2 (1 and $10 \mathrm{nM}$ ) does not affect expression of apelin or its receptor in OVCAR-3 cells [7]. These results indicate that apelin does not abrogate E2-stimulated cell proliferation by altering estrogen receptor expression. Next, we investigated whether crosstalk occurs between APLNR and estrogen receptors. Pharmacological inhibition of APLNR and ER $\alpha$ abrogated the effects of E2 and apelin on proliferation of OVCAR-3 cells, while pharmacological inhibition of ER $\beta$ and GPR30 did not. A possible interaction between adipokine and estrogen receptors has been reported. Fusco et al. [60] demonstrated a significant correlation between expression of the leptin receptor and ER $\alpha$. Additionally, leptin indirectly promotes proliferation and migration of breast cancer cells via estrogen signaling pathways, indicating that hormone-mediated pro-carcinogenic crosstalk occurs [61]. Our results demonstrate for the first time that crosstalk occurs between APLNR and ER $\alpha$ in epithelial ovarian cancer cells.

Role of IGF-1 in regulation of ovarian functions and steroidogenesis is already well known $[62,63]$. Interactions between IGF-1 and other hormones produced by ovarian cells are important for proper functioning of human ovaries. The present study showed that apelin in combination with IGF-1 stimulated proliferation of OVCAR-3 cells, and this effect was not greater than that of each compound alone. Similarly, Rak et al. [64] reported that IGF-1 significantly increases cell proliferation in porcine ovarian follicles, although apelin $(2 \mathrm{ng} / \mathrm{ml})$ does not enhance the effects of IGF-1. However, apelin abrogated IGF-1-stimulated proliferation of COV434 cells. It is worth noting that apelin alone did not affect proliferation of COV434 cells, similar to chemerin. Consistently, we previously reported that adiponectin abrogates the stimulatory effect of IGF-1 on proliferation of OVCAR-3 cells [54]. Moreover, we demonstrated that these effects were not mediated via the ERK1/2 and PI3K pathways using chemical inhibitors. These signaling pathways were examined because binding of IGF-1 to its tyrosine kinase receptor IGF1R activates PI3K/Akt and MAPK/ERK, leading to changes in cell proliferation, differentiation, and apoptosis [65, 66]. Moreover, apelin increases IGF-1-induced phosphorylation of PI3K/Akt [58] and regulates steroidogenesis in granulosa cells $[67,68]$. Roche et al. [58] reported that the PI3K/Akt signaling pathway is involved in the effects of apelin on IGF-1-induced steroidogenesis in granulosa cells using pharmacological inhibitors. However, the current study demonstrated that the ERK1/2 and PI3K pathways do not mediate the antagonistic effect of apelin on IGF-1-induced proliferation of COV434 cells. Next, we investigated whether apelin affects proliferation of COV434 cells by altering IGF1R expression or whether this effect is mediated by interactions between receptors. Treatment with apelin at concentrations measured in granulosa cells and serum did not affect mRNA expression of IGF1R. However, pretreatment with the APLNR antagonist ML221 abrogated IGF-1-stimulated proliferation of COV434 cells, 


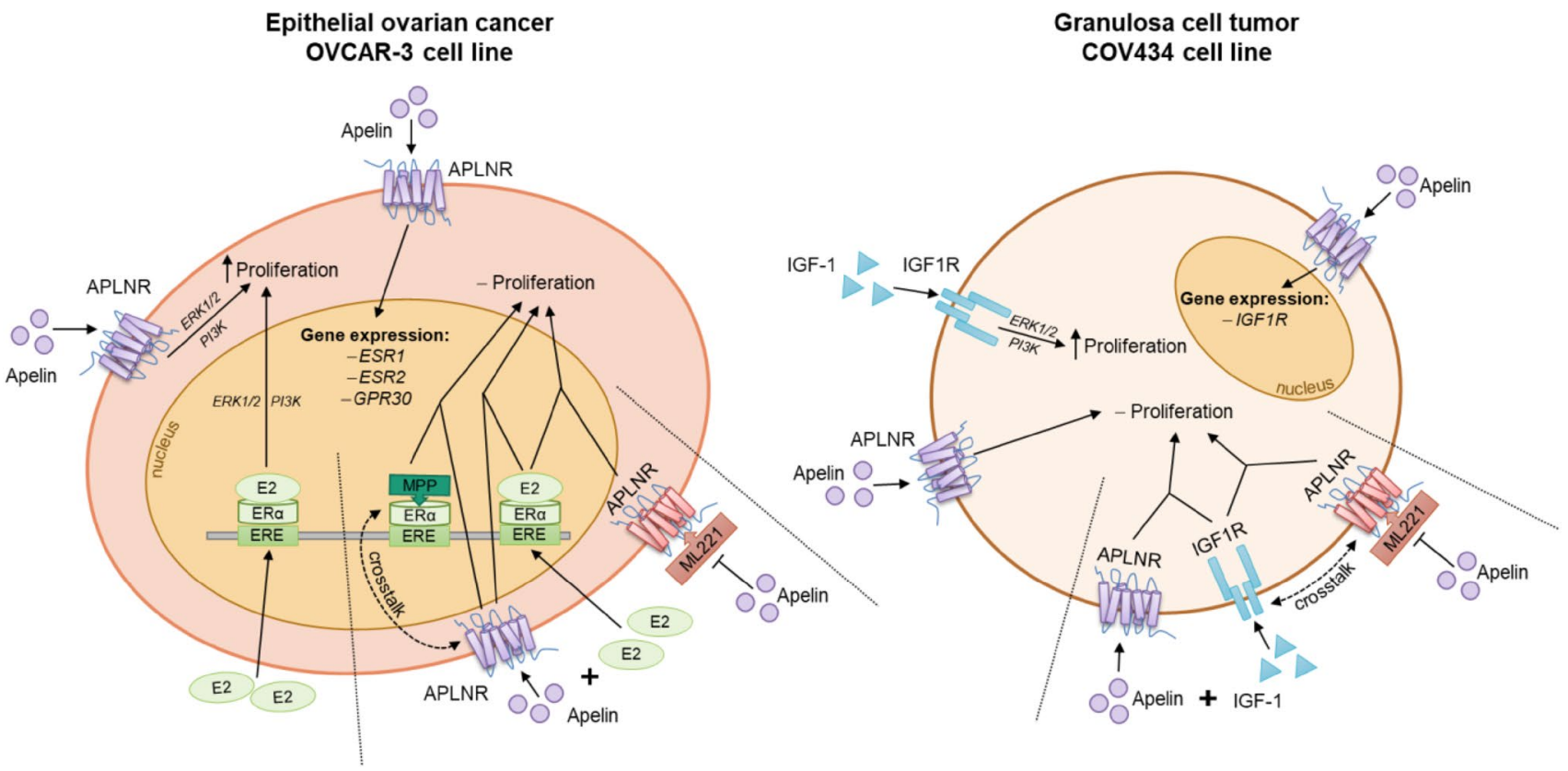

Fig. 8 Schematic overview of the effects of apelin on E2 and IGF-1 as well as potential crosstalk between APLNR and ER $\alpha /$ IGF1R in OVCAR-3 and COV434 cells. E2 17 $\beta$-estradiol, APLNR apelin receptor, $I G F-1$ insulin-like growth factor-1, $I G F I R$ insulin-like growth factor-1 receptor, $E R \alpha$ estrogen receptor alpha, $E R \beta$ estrogen receptor

indicating that inhibition of APLNR causes IGF1R dysfunction. Crosstalk between adiponectin, a well-known adipokine, and IGF1R was previously reported; adiponectin increases tyrosine phosphorylation of the $\beta$ subunit of IGF1R and downstream MAPK activation in rat granulosa cells [1]. Mauro et al. [69] reported that crosstalk between adiponectin/AdipoR1 and IGF1R rapidly increases phosphorylation of IGF1R in ER $\alpha$-positive breast cancer cells. Saxena et al. [70] demonstrated that bidirectional crosstalk between leptin and IGF-1 signaling transactivates vascular endothelial growth factor receptor-1 and promotes metastasis, invasion, and migration of breast cancer cells. However, Ozbay and Nahta [71] showed that IGF-1 stimulates phosphorylation and activation of $\mathrm{Ob}-\mathrm{R}$ while leptin does not induce phosphorylation of IGF1R, indicating that this regulation is unidirectional. To the best of our knowledge, there is no information regarding the relationship between APLNR inhibition and IGF1R dysfunction. We surmise that negative crosstalk occurs between these two receptors and that this underlies the antagonistic effect of apelin on IGF1 -induced proliferation of COV434 cells.

In conclusion, apelin and chemerin did not affect caspase- 3 activation in epithelial and granulosa ovarian cancer cell lines. Apelin abolished the stimulatory effects of E2 on proliferation of OVCAR-3 cells and of IGF-1 on proliferation of COV434 cells. We speculate that these effects beta, GPR30 G protein-coupled receptor 30, ML221 APLNR antagonist, MPP ER $\alpha$ antagonist, PHTPP ER $\beta$ antagonist, G15 GPR30 antagonist, ESR1 gene encoding ER $\alpha, E S R 2$ gene encoding ER $\beta$, GPR30 gene encoding GPR30, IGF1R gene encoding IGF1R. The arrow facing up indicates a stimulation; dash indicates no influence

are mediated via crosstalk between APLNR and ER $\alpha /$ IGF1R (Fig. 8).

Funding This work was supported by the National Science Centre (NCN), Poland [Grant Number 2016/21/N/NZ5/00161].

\section{Compliance with ethical standards}

Conflict of interest The authors declare that they have no conflict of interest.

Open Access This article is distributed under the terms of the Creative Commons Attribution 4.0 International License (http://creativeco mmons.org/licenses/by/4.0/), which permits unrestricted use, distribution, and reproduction in any medium, provided you give appropriate credit to the original author(s) and the source, provide a link to the Creative Commons license, and indicate if changes were made.

\section{References}

1. Chabrolle C, Tosca L, Dupont J (2007) Regulation of adiponectin and its receptors in rat ovary by human chorionic gonadotrophin treatment and potential involvement of adiponectin in granulosa cell steroidogenesis. Reproduction 133:719-731

2. Maillard V, Uzbekova S, Guignot F, Perreau C, Ramé C, Coyral-Castel S, Dupont J (2010) Effect of adiponectin on bovine 
granulosa cell steroidogenesis, oocyte maturation and embryo development. Reprod Biol Endocrinol 8:23

3. Maillard V, Froment P, Ramé C, Uzbekova S, Elis S, Dupont J (2011) Expression and effect of resistin on bovine and rat granulosa cell steroidogenesis and proliferation. Reproduction 141:467-479

4. Rak-Mardyla A (2013) Ghrelin role in hypothalamus-pituitaryovarian axis. J Physiol Pharmacol 64:695-704

5. Schilffarth S, Antoni B, Schams D, Meyer HH, Berisha B (2009) The expression of apelin and its receptor APJ during different physiological stages in the bovine ovary. Int J Biol Sci 5:344-350

6. Wang Q, Leader A, Tsang BK (2013) Inhibitory roles of prohibitin and chemerin in FSH-induced rat granulosa cell steroidogenesis. Endocrinology 154:956-967

7. Hoffmann M, Fiedor E, Ptak A (2017) Bisphenol A and its derivatives tetrabromobisphenol $\mathrm{A}$ and tetrachlorobisphenol $\mathrm{A}$ induce apelin expression and secretion in ovarian cancer cells through a peroxisome proliferator-activated receptor gamma-dependent mechanism. Toxicol Lett 269:15-22

8. Hoffmann M, Rak A, Ptak A (2018) Bisphenol A and its derivatives decrease expression of chemerin, which reverses its stimulatory action in ovarian cancer cells. Toxicol Lett 291:61-69

9. O'Dowd BF, Heiber M, Chan A, Heng HH, Tsui LC, Kennedy JL, Shi X, Petronis A, George SR, Nguyen T (1993) A human gene that shows identity with the gene encoding the angiotensin receptor is located on chromosome 11. Gene 136:355-360

10. Tatemoto K, Hosoya M, Habata Y, Fujii R, Kakegawa T, Zou MX, Kawamata Y, Fukusumi S, Hinuma S, Kitada C, Kurokawa T, Onda H, Fujino M (1998) Isolation and characterization of a novel endogenous peptide ligand for the human APJ receptor. Biochem Biophys Res Commun 251:471-476

11. Hu PF, Tang JL, Chen WP, Bao JP, Wu LD (2011) Increased apelin serum levels and expression in human chondrocytes in osteoarthritic patients. Int Orthop 35:1421-1426

12. Rayalam S, Della-Fera MA, Kasser T, Warren W, Baile CA (2011) Emerging role of apelin as a therapeutic target in cancer: a patent review. Recent Pat Anticancer Drug Discov 6:367-372

13. Berta J, Kenessey I, Dobos J, Tovari J, Klepetko W, Jan Ankersmit H, Hegedus B, Renyi-Vamos F, Varga J, Lorincz Z, Paku S, Ostoros G, Rozsas A, Timar J, Dome B (2010) Apelin expression in human non-small cell lung cancer: role in angiogenesis and prognosis. J Thorac Oncol 5:1120-1129

14. Taheri S, Murphy K, Cohen M, Sujkovic E, Kennedy A, Dhillo W, Dakin C, Sajedi A, Ghatei M, Bloom S (2002) The effects of centrally administered apelin-13 on foodintake, water intake and pituitary hormone release in rats. Biochem Biophys Res Commun 291:1208-1212

15. Bertrand C, Valet P, Castan-Laurell I (2015) Apelin and energy metabolism. Front Physiol 6:115

16. Berta J, Hoda MA, Laszlo V, Rozsas A, Garay T, Torok S, Grusch M, Berger W, Paku S, Renyi-Vamos F, Masri B, Tovari J, Groger M, Klepetko W, Hegedus B, Dome B (2014) Apelin promotes lymphangiogenesis and lymph node metastasis. Oncotarget 5:4426-4437

17. Sorli SC, Le Gonidec S, Knibiehler B, Audigier Y (2007) Apelin is a potent activator of tumour neoangiogenesis. Oncogene 26:7692-7699

18. Picault FX, Chaves-Almagro C, Projetti F, Prats H, Masri B, Audigier Y (2014) Tumour co-expression of apelin and its receptor is the basis of an autocrine loop involved in the growth of colon adenocarcinomas. Eur J Cancer 50:663-674

19. Yang L, Su T, Lv D, Xie F, Liu W, Cao J, Sheikh IA, Qin X, Li L, Chen L (2014) ERK1/2 mediates lung adenocarcinoma cell proliferation and autophagy induced by apelin-13. Acta Biochim Biophys Sin 46:100-111
20. Heo K, Kim YH, Sung HJ, Li HY, Yoo CW, Kim JY, Park JY, Lee UL, Nam BH, Kim EO, Kim SY, Lee SH, Park JB, Choi SW (2012) Hypoxia-induced up-regulation of apelin is associated with a poor prognosis in oral squamous cell carcinoma patients. Oral Oncol 48:500-506

21. Zabel BA, Allen SJ, Kulig P, Allen JA, Cichy J, Handel TM, Butcher EC (2005) Chemerin activation by serine proteases of the coagulation, fibrinolytic, and inflammatory cascades. J Biol Chem 280:34661-34666

22. Chu SH, Lee MK, Ahn KY, Im JA, Park MS, Lee DC, Jeon JY, Lee JW (2012) Chemerin and adiponectin contribute reciprocally to metabolic syndrome. PLoS ONE 7:34710

23. Shin HY, Lee DC, Chu SH, Jeon JY, Lee MK, Im JA, Lee JW (2012) Chemerin levels are positively correlated with abdominal visceral fat accumulation. Clin Endocrinol (Oxf) 77:47-50

24. Garces MF, Sanchez E, Ruíz-Parra AI, Rubio-Romero JA, AngelMüller E, Suarez MA, Bohórquez LF, Bravo SB, Nogueiras R, Diéguez C, Caminos JE (2013) Serum chemerin levels during normal human pregnancy. Peptides 42:138-143

25. Guzel EC, Celik C, Abali R, Kucukyalcin V, Celik E, Guzel M, Yilmaz M (2014) Omentin and chemerin and their association with obesity in women with polycystic ovary syndrome. Gynecol Endocrinol 30:419-422

26. Meric M, Soylu K, Avci B, Yuksel S, Gulel O, Yenercag M, Coksevim M, Uzun A (2014) Evaluation of plasma chemerin levels in patients with non-dipper blood pressure patterns. Med Sci Monit 28:698-705

27. Zhang J, Jin HC, Zhu AK, Ying RC, Wei W, Zhang FJ (2014) Prognostic significance of plasma chemerin levels in patients with gastric cancer. Peptides 61:7-11

28. Rama D, Esendagli G, Guc D (2011) Expression of chemokinelike receptor 1 (CMKLR1) on J744A.1 macrophages co-cultured with fibroblast and/or tumor cells: modeling the influence of microenvironment. Cell Immunol 271:134-140

29. Reverchon $\mathrm{M}$, Cornuau $\mathrm{M}$, Ramé $\mathrm{C}$, Guerif $\mathrm{F}$, Royère $\mathrm{D}$, Dupont J (2012) Chemerin inhibits IGF-1-induced progesterone and estradiol secretion in human granulosa cells. Hum Reprod 27:1790-1800

30. Ferlay J, Soerjomataram I, Ervik M, Dikshit R, Eser S, Mathers C (2013) GLOBOCAN 2012 v1.0, Cancer Incidence and Mortality Worldwide: IARC Cancer Base No. 11. International Agency for Research on Cancer, Lyon

31. Howlader N, Noone AM, Krapcho M (2015) SEER cancer statistics review, 1975-2013. National Cancer Institute. Bethesa, MD, http://seer.cancer.gov/csr/1975_2013/, based on November 2015 SEER data submission, posted to the SEER website, April 2016

32. Sankaranarayanan R, Ferlay J (2006) Worldwide burden of gynaecological cancer: the size of the problem. Best Pract Res Clin Obstet Gynaecol 20:207-225

33. Mungenast F, Thalhammer T (2014) Estrogen biosynthesis and action in ovarian cancer. Front Endocrinol (Lausanne) 5:192

34. Shen MR, Lin AC, Hsu YM, Chang TJ, Tang MJ, Alper SL, Ellory JC, Chou CY (2004) Insulin-like growth factor 1 stimulates $\mathrm{KCl}$ cotransport, which is necessary for invasion and proliferation of cervical cancer and ovarian cancer cells. J Biol Chem 279:40017-40025

35. Tanaka Y, Kobayashi H, Suzuki M, Hirashima Y, Kanayama N, Terao T (2004) Genetic downregulation of pregnancy-associated plasma protein-A (PAPP-A) by bikunin reduces IGF-I-dependent Akt and ERK1/2 activation and subsequently reduces ovarian cancer cell growth, invasion and metastasis. Int J Cancer 109:336-347

36. Cao Z, Liu LZ, Dixon DA, Zheng JZ, Chandran B, Jiang BH (2007) Insulin-like growth factor-I induces cyclooxygenase-2 expression via PI3K, MAPK and PKC signaling pathways in human ovarian cancer cells. Cell Signal 19:1542-1553 
37. De Marco P, Bartella V, Vivacqua A, Lappano R, Santolla MF, Morcavallo A, Pezzi V, Belfiore A, Maggiolini M (2013) Insulinlike growth factor-I regulates GPER expression and function in cancer cells. Oncogene 32:678-688

38. Livak KJ, Schmittgen TD (2001) Analysis of relative gene expression data using real-time quantitative PCR and the 2(-Delta Delta $\mathrm{C}(\mathrm{T})$ ) method. Methods 25:402-408

39. Reverchon M, Ramé C, Bertoldo M, Dupont J (2014) Adipokines and the female reproductive tract. Int J Endocrinol 2014:232454

40. Boal F, Timotin A, Roumegoux J, Alfarano C, Calise D, Anesia R, Parini A, Valet P, Tronchere H, Kunduzova O (2016) Apelin-13 administration protects against ischaemia/reperfusion-mediated apoptosis through the FoxO1 pathway in high-fat diet-induced obesity. Br J Pharmacol 173:1850-1863

41. Zhang Z, Yu B, Tao GZ (2009) Apelin protects against cardiomyocyte apoptosis induced by glucose deprivation. Chin Med J (Engl) 122:2360-2365

42. Zhang H, Chen S, Zeng M, Lin D, Wang Y, Wen X, Xu C, Yang L, Fan X, Gong Y, Zhang H, Kong X (2018) Apelin-13 administration protects against LPS-induced acute lung injury by inhibiting NF- $\kappa \mathrm{B}$ pathway and NLRP3 inflammasome activation. Cell Physiol Biochem 49:1918-1932

43. Tang SY, Xie H, Yuan LQ, Luo XH, Huang J, Cui RR, Zhou HD, Wu XP, Liao EY (2007) Apelin stimulates proliferation and suppresses apoptosis of mouse osteoblastic cell line MC3T3-E1 via JNK and PI3-K/Akt signaling pathways. Peptides 28:708-718

44. Yang Y, Zhang XJ, Li LT, Cui HY, Zhang C, Zhu CH, Miao JY (2016) Apelin-13 protects against apoptosis by activating AMPactivated protein kinase pathway in ischemia stroke. Peptides 75:96-100

45. Wu F, Qiu J, Fan Y, Zhang Q, Cheng B, Wu Y, Bai B (2018) Apelin-13 attenuates ER stress-mediated neuronal apoptosis by activating $\mathrm{G} \alpha(\mathrm{i}) / \mathrm{G} \alpha(\mathrm{q})-\mathrm{CK} 2$ signaling in ischemic stroke. Exp Neurol 302:136-144

46. Liu DR, Hu W, Chen GZ (2018) Apelin-12 exerts neuroprotective effect against ischemia-reperfusion injury by inhibiting JNK and P38MAPK signaling pathway in mouse. Eur Rev Med Pharmacol Sci 22:3888-3895

47. Zeng H, He X, Hou X, Li L, Chen JX (2014) Apelin gene therapy increases myocardial vascular density and ameliorates diabetic cardiomyopathy via upregulation of sirtuin 3. Am J Physiol Heart Circ Physiol 306:585-597

48. Lu Q, Jiang YR, Qian J, Tao Y (2013) Apelin-13 regulates proliferation, migration and survival of retinal Müller cells under hypoxia. Diabetes Res Clin Pract 99:158-167

49. Andersen CU, Hilberg O, Mellemkjær S, Nielsen-Kudsk JE, Simonsen U (2011) Apelin and pulmonary hypertension. Pulm Circ 1:334-346

50. Roche J, Ramé C, Reverchon M, Mellouk N, Rak A, Froment P, Dupont J (2017) Apelin (APLN) regulates progesterone secretion and oocyte maturation in bovine ovarian cells. Reproduction 153:589-603

51. Rodríguez-Penas D, Feijóo-Bandín S, García-Rúa V, MosqueraLeal A, Durán D, Varela A, Portolés M, Roselló-Lletí E, Rivera M, Diéguez C, Gualillo O, González-Juanatey JR, Lago F (2015) The adipokine chemerin induces apoptosis in cardiomyocytes. Cell Physiol Biochem 37:176-192

52. Lindgren PR, Bäckström T, Cajander S, Damber MG, Mählck CG, Zhu D, Olofsson JI (2002) The pattern of estradiol and progesterone differs in serum and tissue of benign and malignant ovarian tumors. Int J Oncol 21:583-589

53. Hoffmann M, Fiedor E, Ptak A (2016) 17 $\beta$-Estradiol reverses leptin-inducing ovarian cancer cell migration by the PI3K/Akt signaling pathway. Reprod Sci 23:1600-1608

54. Hoffmann M, Gogola J, Ptak A (2018) Adiponectin reverses the proliferative effects of estradiol and IGF-1 in human epithelial ovarian cancer cells by downregulating the expression of their receptors. Horm Cancer 9:166-174

55. Robker RL, Richards JS (1998) Hormone-induced proliferation and differentiation of granulosa cells: a coordinated balance of the cell cycle regulators cyclin D2 and p27Kip1. Mol Endocrinol 12:924-940

56. François CM, Wargnier R, Petit F, Goulvent T, Rimokh R, Treilleux I, Ray-Coquard I, Zazzu V, Cohen-Tannoudji J, Guigon CJ (2015) 17 $\beta$-estradiol inhibit sspreading of metastatic cells from granulosa cell tumors through a non-genomic mechanism involving GPER1. Carcinogenesis 36:564-573

57. Ptak A, Hoffmann M, Gruca I, Barć J (2014) Bisphenol A induce ovarian cancer cell migration via the MAPK and PI3K/Akt signalling pathways. Toxicol Lett 229:357-365

58. Roche J, Ramé C, Reverchon M, Mellouk N, Cornuau M, Guerif F, Froment P, Dupont J (2016) Apelin (APLN) and Apelin Receptor (APLNR) in human ovary: expression, signaling, and regulation of steroidogenesis in primary human luteinized granulosa cells. Biol Reprod 95:104

59. Peng X, Li F, Wang P, Jia S, Sun L, Huo H (2015) Apelin-13 induces MCF-7 cell proliferation and invasion via phosphorylation of ERK1/2. Int J Mol Med 36:733-738

60. Fusco R, Galgani M, Procaccini C, Franco R, Pirozzi G, Fucci L, Laccetti P, Matarese G (2010) Cellular and molecular crosstalk between leptin receptor and estrogen receptor-\{alpha\} in breast cancer: molecular basis for a novel therapeutic setting. Endocr Relat Cancer 17:373-382

61. Rene Gonzalez R, Watters A, Xu Y, Singh UP, Mann DR, Rueda BR, Penichet ML (2009) Leptin-signaling inhibition results in efficient anti-tumor activity in estrogen receptor positive or negative breast cancer. Breast Cancer Res 11:R36

62. Giudice LC (1992) Insulin-like growth factors and ovarian follicular development. Endocr Rev 13:641-669

63. Cataldo NA, Giudice LC (1992) Insulin-like growth factor binding protein profiles in human ovarian follicular fluid correlate with follicular functional status. J Clin Endocrinol Metab 74:821-829

64. Rak A, Drwal E, Rame C, Knapczyk-Stwora K, Słomczyńska M, Dupont J, Gregoraszczuk EL (2017) Expression of apelin and apelin receptor (APJ) in porcine ovarian follicles and in vitro effect of apelin on steroidogenesis and proliferation through APJ activation and different signaling pathways. Theriogenology 96:126-135

65. Butler AA, Yakar S, Gewolb IH, Karas M, Okubo Y, LeRoith D (1998) Insulin-like growth factor-I receptor signal transduction: at the interface between physiology and cell biology. Comp Biochem Physiol B 121:19-26

66. Sabbatini P, Rowand JL, Groy A, Korenchuk S, Liu Q, Atkins C, Dumble M, Yang J, Anderson K, Wilson BJ, Emmitte KA, Rabindran SK, Kumar R (2009) Antitumor activity of GSK1904529A, a small-molecule inhibitor of the insulinlike growth factor-I receptor tyrosine kinase. Clin Cancer Res 15:3058-3067

67. Zhou P, Baumgarten SC, Wu Y, Bennett J, Winston N, HirshfeldCytron J, Stocco C (2013) IGF-I signaling is essential for FSH stimulation of AKT and steroidogenic genes in granulosa cells. Mol Endocrinol 27:511-523

68. Gyles SL, Burns CJ, Whitehouse BJ, Sugden D, Marsh PJ, Persaud SJ, Jones PM (2001) ERKs regulate cyclic AMP-induced steroid synthesis through transcription of the steroidogenic acute regulatory (StAR) gene. J Biol Chem 276:34888-34895

69. Mauro L, Pellegrino M, De Amicis F, Ricchio E, Giordano F, Rizza P, Catalano S, Bonofiglio D, Sisci D, Panno ML, Andò $S$ (2014) Evidences that estrogen receptor $\alpha$ interferes with adiponectin effects on breast cancer cell growth. Cell Cycle 13:553-564

70. Saxena NK, Taliaferro-Smith L, Knight BB, Merlin D, Anania FA, O'Regan RM, Sharma D (2008) Bidirectional crosstalk between 
leptin and insulin-like growth factor-I signaling promotes invasion and migration of breast cancer cells via transactivation of epidermal growth factor receptor. Cancer Res 68:9712-9722

71. Ozbay T, Nahta R (2008) A novel unidirectional cross-talk from the insulin-like growth factor-I receptor to leptin receptor in human breast cancer cells. Mol Cancer Res 6:1052-1058
Publisher's Note Springer Nature remains neutral with regard to jurisdictional claims in published maps and institutional affiliations. 